\title{
Characterization of dried horseradish leaves pomace: phenolic compounds profile and antioxidant capacity, content of organic acids, pigments and volatile compounds
}

\author{
Lolita Tomsone $^{1}$ (1) $\cdot$ Ruta Galoburda $^{1}$ (D) Zanda Kruma $^{1}$ (D) $\cdot$ Ingmars Cinkmanis ${ }^{2}$
}

Received: 12 February 2020 / Revised: 22 May 2020 / Accepted: 23 May 2020 / Published online: 6 June 2020

(c) The Author(s) 2020

\begin{abstract}
Horseradish (Armoracia rusticana) leaves pomace, which contains high-value bioactive compounds, is the product resulting from pressing horseradish leaves for juice production. The aim of the current research was to investigate the effect of convective, microwave-vacuum and freeze-drying on the content of bioactive compounds in horseradish leaves pomace. Convective hot air-drying was performed at 40,60 and $80^{\circ} \mathrm{C}$. The total phenolic content (TPC), total flavonoid content (TFC), total flavan-3-ol content, total phenolic acid content, total flavonol content, chlorophylls and total carotenoids, and antioxidant activity were determined by spectrophotometric methods. Individual profiles of phenols and organic acids are estimated by high-performance liquid chromatography (HPLC), but volatile compounds are estimated by gas chromatography (GC). Totally, 14 individual phenolic compounds, 8 organic acids, and 49 volatile compounds were analysed in the studied samples. The main phenolic compound identified in horseradish leaves pomace was rutin (3231 mg/100 g DW), among organic acids-quinic and malic acids, and volatile compounds-allyl isothiocyanate, 3-butenenitrile and benzyl alcohol. In the drying process, the content of some (total flavan-3-ols, total carotenoids content) compounds increased, but others (TPC, total organic acids content) decreased, and it was drying method-dependent. Freeze-drying caused the reduction of TPC by $29 \%$, whereas convective drying by $53-59 \%$. Fresh pomace contains such isothiocyanates as allyl isothiocyanate and butyl isothiocyanate, which were completely lost in the drying process. Freeze-drying allowed the best retention of various phenolic and volatile compounds in horseradish leaves pomace.
\end{abstract}

Keywords Rutin $\cdot$ Chlorophylls $\cdot$ Carotenoids $\cdot$ Allyl isothiocyanate $\cdot$ Drying method

\section{Introduction}

Horseradish (Armoracia rusticana) leaves pomace is the product resulting from pressing horseradish leaves for juice production. Generally, pomace is considered to be a production waste, which gains a strong interest due to the environmental aspects related to the waste disposal. Additionally, it is well documented that production waste, such as peels, seeds, and pomace, contains high-value bioactive

Lolita Tomsone

lolita.tomsone@1lu.lv

1 Department of Food Technology, Latvia University of Life Sciences and Technologies, Rigas Street 22, Jelgava 3004, Latvia

2 Department of Chemistry, Latvia University of Life Sciences and Technologies, Liela Street 1, Jelgava 3001, Latvia compounds [1,2]. Thus, pomace can be used as a source of phenolics and other bioactives possessing antioxidant power. However, the use of pomace is limited by its high moisture content, which reduces the shelf life. Therefore, processing of waste is required to extend its possible use. But, processing may result in unwanted changes of bioactive compounds [3]. Drying, among other processing methods, is widely used to inhibit enzyme and microbial activity [4]. In food processing, variety of drying technologies with various processing parameters are used [3].

Convective drying is one of the most popular drying methods, which is based on the moisture removal by hot air. As a result of thermal effect, volatile compounds may be lost during air-drying [5]. However, due to cell wall damage, some compounds may be released and become more easily extracted. Additionally, as a result of oxidative reactions or glycosidic hydrolysis of new compounds, which are not present in fresh samples, may be formed [6]. 
To increase the process efficiency and reduce costs, as well as to preserve product quality, alternative dehydration methods, such as microwave-vacuum (MW) and freezedrying (FD), are used.

In the MW drying, compared to the traditional drying technologies, lower temperatures are used and vacuum along with volumetric heating increases the drying rate [7]. It results in shorter drying time, which reduces the possible damage to food compounds due to oxidation and thermal degradation [8]. It results in a better preservation of thermally unstable bioactive compounds present in the product being dried.

Freeze-drying, which unlike other drying methods takes place at low temperatures, is suitable for elimination of heatinduced degradation of bioactives [8]. However, relatively high expense is the major limitation of this method [9].

In the drying process, fruit and vegetable phenolics are exposed to various temperatures and oxygen, resulting in chemical and biochemical degradation reactions, which may induce formation of new compounds of different bioactivity compared to the initial material. Scientific literature reveals contradictory data on drying effect on phenolic content in plant materials because bioactive compounds may have different response to temperature, oxygen, light, and other physical factors due to the biological diversity and chemical structure [10], as well as drying method and process parameters-temperature, duration, microwave power, pressure, etc. [3, 10].

Similarly, initial volatile composition, food matrix, variety, developmental stage, and drying method and its parameters affect volatile profile of dried products [6, 12]. Drying may cause interaction among volatile compounds as well as induce other reactions, resulting in loss of initially present volatiles responsible for aroma, flavour and taste of the product [13]. Earlier studies proved that the most effective method for preservation of volatiles in aerial parts of coriander is freeze-drying [14]. In hot air-drying, an increased loss of volatiles is observed at higher drying temperature. According to Calín-Sánchez et al. [11], the most suitable drying method for volatile preservation in sweet bail plants (O. basilicum L.) was combined method-convective predrying and microwave finish-drying $\left(40{ }^{\circ} \mathrm{C}\right.$ and $\left.360 \mathrm{~W}\right)$ because of short drying time (approx. $250 \mathrm{~min}$ ). In the final product, they reported high concentration of volatiles and sensory profile typical for high-quality dried products. Despite FD is not a very popular method for plant drying, it effectively retains volatile compounds in grape skins [15] and jabuticaba peel [16].

To the best of our knowledge, this is the first study that aimed to investigate the effect of convective, microwavevacuum and freeze-drying on the content of total phenolics, flavonoids, flavan-3-ols, phenolic acids, individual phenols, antioxidative capacities, organic acids, pigments, and volatile compound profiles in horseradish leaves pomace (HRLP).

\section{Materials and methods}

\section{Plant materials and chemicals}

Fresh horseradish (Armoracia rusticana $\mathrm{L}$.) leaves were collected in Latvia (latitude: $56^{\circ} 40^{\prime} \mathrm{N}$, longitude: $23^{\circ} 30^{\prime}$ E) in July 2018. Leaves were washed, placed on the moisture-absorbing surface until fully dried (approximately $2 \mathrm{~h}$ ), and cut into $5.0 \pm 0.5 \mathrm{~cm}$ long pieces. The samples of $0.25 \mathrm{~kg}$ each were packaged in the hermetically sealed polypropylene (PP) pouches and then frozen at $-20{ }^{\circ} \mathrm{C}$ and stored until processing (Fig. 1). Frozen horseradish leaves were ground for juice extraction in a basket press.

The remaining horseradish leaves pomace (HRLP) was then dried till dry matter content $92-97 \%$ using the following methods:

a) freeze-drying in a vacuum freeze-dryer FT333 (Armfield Ltd, UK) at $-40{ }^{\circ} \mathrm{C}$ and $6.4 \mathrm{~Pa}$ pressure, drying time $72 \mathrm{~h}$;

b) microwave-vacuum drying in a dryer Musson-1 (Ingredient, Russia) for at a drum rotation speed of $6 \mathrm{rpm}$, pressure of $12.00-14.63 \mathrm{kPa}$, programmed at gradually decreasing microwave power level, starting with 4 operating magnetrons, then 3, 2, 1 magnetrons (each $640 \mathrm{~W}$ ), drying time for $2 \mathrm{~kg}$ of fresh product $45 \mathrm{~min}$;

c) convective hot air-drying in a Universal Oven UF160 (Memmert GmbH + Co.KG, Germany) at 40, 60 and $80{ }^{\circ} \mathrm{C}$ until the moisture content was below $8 \%$, which requires drying time 6,5 and $4 \mathrm{~h}$, respectively.

Fresh HRLP was used as a control sample.

The moisture content was determined in triplicate according to the standard ISO 6496:1999 (LVS 272:2000) for expressing results on dry basis.

All the following chemicals were of analytical or highperformance liquid chromatography (HPLC) grade. Gallic acid, Folin-Ciocalteu phenol reagent, and 2,2-diphenyl1-picrylhydrazyl (DPPH') were purchased from SigmaAldrich (Switzerland). All other chemicals used in the research were obtained from Acros Organic (USA). 
Fig. 1 Horseradish leaves processing flowchart

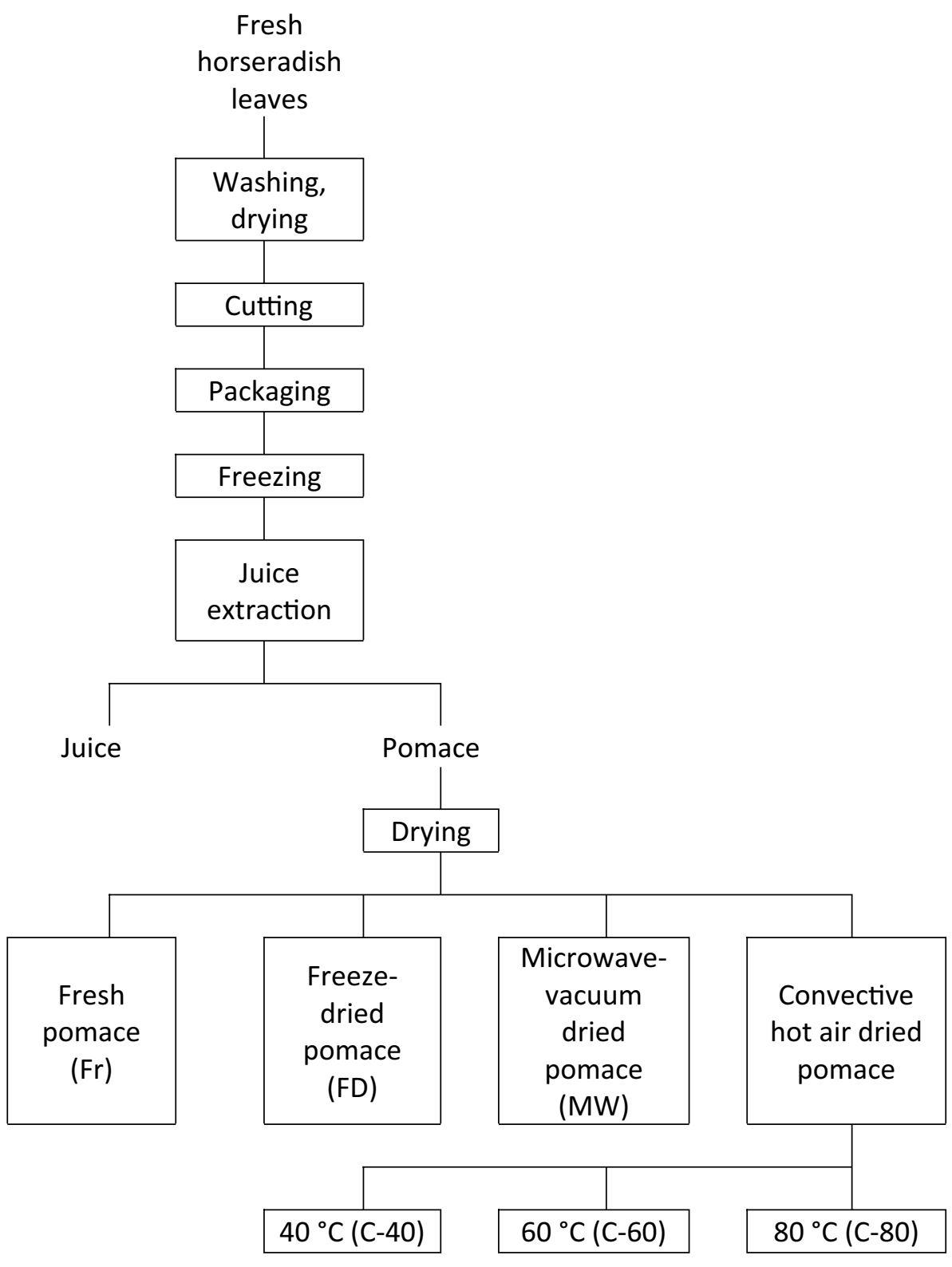

Determination of total phenolic content (TPC), total flavonoid content (TFC), total flavan-3-ol content, total phenolic acid content, total flavonol content and antioxidant activity

\section{Extraction procedure}

HRLP for spectrophotometric analysis was ground to fine particles and homogenized to a particle size of $0.5 \mu \mathrm{m}$. Weight of samples for multiple extractions was selected to obtain equal dry matter mass, namely, $1.00 \pm 0.01 \mathrm{~g}$ of fresh pomace $(\mathrm{Fr})$ and $0.25 \pm 0.01 \mathrm{~g}$ of dried pomace. First, samples were twice extracted with $10 \mathrm{~mL}$ acetone in an ultrasonic bath YJ5120-1 (Oubo Dental, USA) at $35 \mathrm{kHz}$ for 30 min at $20 \pm 1{ }^{\circ} \mathrm{C}$. The extracts were then separated in a centrifuge CM-6MT (Elmi Ltd., Latvia) at 3,500 rpm for $10 \mathrm{~min}$. The supernatants were combined into $25 \mathrm{~mL}$ graduated flask and filled up to the mark with the solvent. The residues were re-extracted with ethanol:water 80:20 (v/v) using the same procedure. Quantification was done using a JENWAY 6300 spectrophotometer (Baroworld Scientifid Ltd., UK). Results were calculated as a sum of acetone and ethanol extracts using respective calibration curves. The extraction process was done in triplicate.

\section{Spectrophotometric analysis}

TPC was determined according to the Folin-Ciocalteu spectrophotometric method described by Singleton et al. [17] 
and is expressed as GAE/100 g dry weight (DW) of plant material.

TFC was determined according to the colorimetric method described by Kim et al. [18] with modifications given by Blasco et al. [19] and is expressed as CE/100 g DW of plant material.

The flavan-3-ol (proanthocyanidins) content was determined by Zam et al. [20] method and is expressed as $\mathrm{CE} / 100 \mathrm{~g}$ DW of plant material.

The phenolic acid content was determined by GawlikDziki [21] method and is expressed as CAE/100 g DW of plant material.

The total flavonol content was determined by Ložiene et al. [22] method and is expressed as RE/100 g DW of plant material.

The 2,2-diphenyl-1-picrylhydrazyl ( $\mathrm{DPPH}^{*}$ ) radical-scavenging activity was determined by Yu et al. [23] method. The radical-scavenging activity of extract was also measured by $2,2^{\prime}$-azino-bis(3-ethylbenz-thiazoline-6-sulfonic) acid $\left(\mathrm{ABTS}^{\cdot+}\right.$ ) radical cation assay by $\mathrm{Re}$ et al. [24] method. Both antioxidant activities are expressed as TE/100 g DW of plant material.

The reducing power was determined according to Athukorala et al. [25]. This parameter is expressed as AAE per $100 \mathrm{~g}$ DW of plant material.

\section{Analysis of individual phenols}

Weight of HRLP samples for extraction was selected to obtain equal dry matter mass, namely, $5.00 \pm 0.01 \mathrm{~g}$ of fresh pomace (Fr) and $1.25 \pm 0.01 \mathrm{~g}$ of dried pomace, and twice extracted with $10 \mathrm{~mL}$ of $1 \mathrm{~N} \mathrm{HCl} / \mathrm{ET} / \mathrm{H}_{2} \mathrm{O}(1 / 80 / 19 \mathrm{v} / \mathrm{v} / \mathrm{v})$ in an ultrasonic bath YJ5120-1 (Oubo Dental, USA) at $35 \mathrm{kHz}$ for $10 \mathrm{~min}$ at $20 \pm 1{ }^{\circ} \mathrm{C}$. The extracts were then centrifuged in a centrifuge CM-6MT (Elmi Ltd., Latvia) at 3,500 rpm for $5 \mathrm{~min}$. The supernatants were combined into $25 \mathrm{~mL}$ graduated flask and filled up to the mark with the solvent. The quantification was carried out using a Shimadzu liquid chromatograph LC-20AD with the analytical column C18, photodiode array detector SPD-M20A, according to the procedure described by Priecina et al. [26].

\section{Determination of organic acids}

Weight of HRLP samples for extraction was selected to obtain equal dry matter mass, namely, $5.00 \pm 0.01 \mathrm{~g}$ for fresh pomace $(\mathrm{Fr})$ and $1.25 \pm 0.01 \mathrm{~g}$ for dried pomace, and extracted with freshly prepared $\mathrm{m}$-phosphoric acid in distilled water $(\mathrm{pH}=3.00 \pm 0.20)$. Extraction was performed using a magnetic stirrer (magnet $4.0 \times 0.5 \mathrm{~cm}$ ) at $700 \mathrm{rpm}$ for $1 \mathrm{~h}$ at room temperature $\left(20 \pm 1{ }^{\circ} \mathrm{C}\right)$. The extracts were then filtered (paper No. 89). The supernatants were placed into $25 \mathrm{~mL}$ graduated flask and filled up to the mark with the solvent.

Determination of oxalic, tartaric, quinic, malic, ascorbic, citric, fumaric, and succinic acids was carried out using high-performance liquid chromatography (HPLC) (Shimadzu LC-20 Prominence, Shimadzu USA Manufacturing Inc., USA), detector DAD SPD-M20A, solvent delivery unit LC-20AD, column oven CTO-20A, auto sampler SIL-20A, system controller CBM-20A and data system LC solution software. Chromatographic parameters, such as the analytical column Perkin Elmer C18, $4.6 \mathrm{~mm} \times 250 \mathrm{~mm}, 5 \mu \mathrm{m}$ and temperature of column $35^{\circ} \mathrm{C}$, - were used for the separation of organic acids at wavelength $210 \mathrm{~nm}$. Injection volume of sample was $10 \mu \mathrm{L}$. Mobile phase: A (acetonitrile) and B (0.05 M KH2PO4) ratio 1:99 in the gradient conditions was used. Initial flow rate was $1.25 \mathrm{~mL} / \mathrm{min}$. Each measuring was carried out three times and the averages are reported. The calibration chromatogram is presented in Fig. 2.

\section{Determination of chlorophylls and carotenoids}

Chlorophyll $a$, chlorophyll $b$ and total carotenoid content were determined by spectrophotometric method [27] with modifications described by Tomsone and Kruma [28]. Weight of HRLP samples for extraction was selected to obtain equal dry matter mass, namely, $0.50 \pm 0.01 \mathrm{~g}$ of fresh pomace (Fr) and $0.10 \pm 0.01 \mathrm{~g}$ of dried pomace, and extracted with $10 \mathrm{~mL}$ acetone using a magnetic stirrer (magnet size $4.0 \times 0.5 \mathrm{~cm}$ ) at $700 \mathrm{rpm}$ for $15 \mathrm{~min}$ at room temperature $\left(20 \pm 1{ }^{\circ} \mathrm{C}\right)$. Extractable chlorophylls $a$ and $b$ as well as total carotenoids were detected at various wavelengths (470, 645 , and $662 \mathrm{~nm}$ ) using a spectrophotometer Jenway 6300
Fig. 2 HPLC calibration chromatogram of individual organic acids $(\mathrm{g} / \mathrm{L})$ recorded at $210 \mathrm{~nm}$

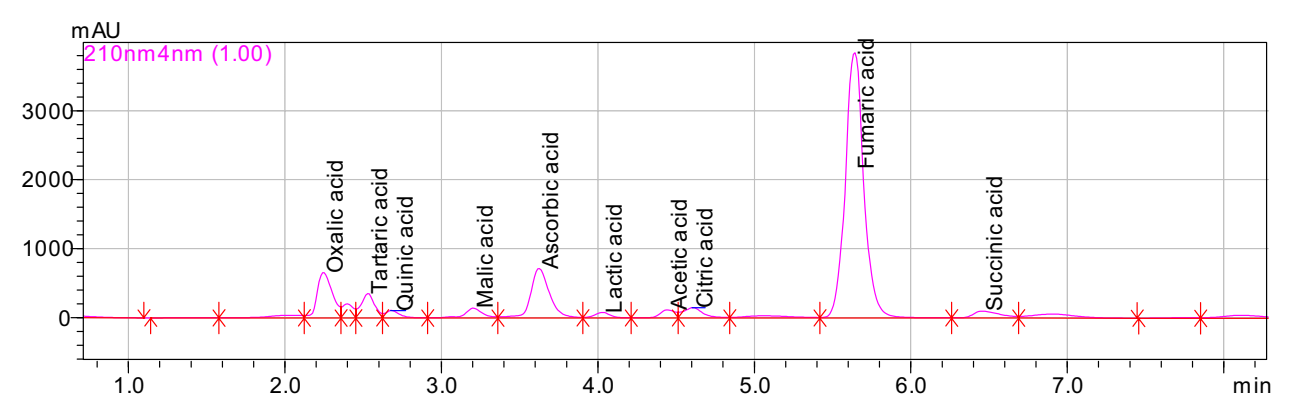


(Baroworld Scientific Ltd., UK) and calculated according to equations described by Tomsone and Kruma [28]. Additionally, total extractable chlorophyll content was expressed as a sum of chlorophylls $a$ and $b$, and the ratio between chlorophylls $\mathrm{R}(a / b)$ was calculated.

\section{Analysis of volatile compounds}

Volatiles from the horseradish leaves pomace were extracted using SPME. 2.00 $\pm 0.01 \mathrm{~g}$ sample of fresh pomace (Fr) and $1.00 \pm 0.01 \mathrm{~g}$ of dried pomace were weighed into a $20 \mathrm{~mL}$ headspace vial. For SPME extraction, a divinylbenzene/ carboxen/polydimethylsiloxane (DVB/Car/PDMS) fiber (Supelco Inc., Bellefonte, PA, USA) was used. The headspace SPME is based on the absorption of the analytes on a fiber coating placed in the sample's headspace volume and on the partition of the target analytes between the sampling matrix and the fiber. SPME parameters were: incubation time $10 \mathrm{~min}$; extraction temperature $35 \pm 1{ }^{\circ} \mathrm{C}$; and extraction duration $10 \mathrm{~min}$. After the extraction, the volatile compounds were thermally desorbed and transferred onto the chromatographic column where they were separated. Desorption parameters were set for $15 \mathrm{~min}$ at $250{ }^{\circ} \mathrm{C}$. For the analysis of the SPME extracts, a Perkin Elmer Clarus 500 GC/MS and an Elite-Wax ETR columns $(60 \mathrm{~m} \times 0.25 \mathrm{~mm}$ i.d.; DF: $0.25 \mu \mathrm{m}$ ) were used. Working conditions were as described by Tomsone et al. [29]. All analyses were performed in triplicate.

\section{Statistical analysis}

Experimental results are means of three parallel measurements and were analysed by Microsoft Excel 2010 and SPSS 17.00. Analysis of variance (ANOVA) and Tukey's test were used to determine the differences among samples. A linear correlation analysis was performed to determine the relationship between TPC, TFC, total flavan-3-ol, total flavonols, total phenolic acid and individual phenol contents, and antioxidant activity, such as $\mathrm{DPPH}^{\circ}, \mathrm{ABTS}^{\circ}{ }^{+}$and reducing power. Differences were considered as significant at $p \leq 0.05$. The principal component analysis (PCA) was used for the evaluation of data on the composition of phenolic compounds and antioxidative activity, as well as the composition of volatiles in HRLP depending on drying conditions.

\section{Results and discussion}

\section{Phenolic compounds}

TPC in fresh horseradish leaves pomace (HRLP) was $4539 \mathrm{mg}$ GAE/100 g DW (Table 1), being higher than TPC in fresh horseradish leaves determined in our previous study
[30], which ranged from $19 \mathrm{mg} \mathrm{GAE} / 100 \mathrm{~g} \mathrm{DW}$ (using conventional extraction with n-hexane) to $3193 \mathrm{mg} \mathrm{GAE} / 100 \mathrm{~g}$ DW (using Soxlet extraction with 95\% ethanol). Another study of TPC in horseradish leaves depending on clones demonstrated the variation between 339 and $2369 \mathrm{mg}$ GAE/100 g DW [31]. According to Marelli et al. [32], the differences in TPC could be explained both by climatic factors, growing conditions, developmental stages and processing conditions.

Drying of HRLP resulted in the significant decrease $(p \leq 0.05)$ in the phenolic content (Table 1) and it was drying method-dependent. Compared to all drying methods studied in the current research, FD better preserved phenolic compounds, namely, FD caused the reduction by $29 \%$, whereas convective drying by $53-59 \%$. Also, drying of guava (Psidium guajava L.) by different methods caused a decrease of TPC [33]. TFC in HRLP, similarly to TPC, was also decreased by $62 \%$ on average after drying compared to fresh pomace. It was in agreement with ginger drying, which showed a decrease of TFC in samples dried at $60{ }^{\circ} \mathrm{C}$ temperature and using microwave power [34]. Conversely, Xiong et al. [35] observed TFC increase in sorghum (Sorghum bicolor L. Moench) grain after treatment at $100{ }^{\circ} \mathrm{C}$ and $150{ }^{\circ} \mathrm{C}$.

Influence of convective drying on HRLP was temperature-dependent and better preservation of TPC was achieved using higher temperature and shorter time. Similar trends for pumpkin by-products were observed by Kḷava et al. [36] who revealed that convective drying at $80{ }^{\circ} \mathrm{C}$ resulted in 21-39\% higher TPC compared to product dried at $40{ }^{\circ} \mathrm{C}$. It is recognized that higher temperatures improve the solubility of phenolic compounds as the hot air facilitates cell structure breakdown, which leads to the release of phenolics from macromolecules [36, 37]. Additionally, TPC reduction could occur due to oxidation enzyme activity (polyphenoloxidase, glycosidase and peroxidase) during lower-temperature $\left(40{ }^{\circ} \mathrm{C}\right)$ drying [39].

At the same time, the total phenolic acid content was by $92 \%$ higher, but total flavan-3-ol content was by $56 \%$ higher in HRLP dried in a convective drier at $80{ }^{\circ} \mathrm{C}$ when compared to the convective drying at $40{ }^{\circ} \mathrm{C}$. In contrast, Wojdyło et al. [9] reported a decrease of 38-44\% in total flavan-3-ol content in jujube fruits after convective drying at increased temperatures $\left(50,60\right.$ and $\left.70{ }^{\circ} \mathrm{C}\right)$.

In HRLP, TFC decreased, which could be explained by thermal degradation during high-temperature treatment [40]. Higher TFC content of guava powder was reported in FD sample compared to oven-dried powder [33]. At increased drying temperature and reduced duration, TFC of HRLP was higher, but opposite trend was observed by Wolfe and Liu [1] in apple peels.

Microwave-vacuum (MW) drying caused a decrease in TPC by $28 \%$, but according to Lim and Murtijaya [40], fast 
Table 1 Phenolic compounds, antioxidant activity, and pigment content in horseradish leaves pomace (HRLP) dried by different methods

\begin{tabular}{|c|c|c|c|c|c|c|}
\hline \multirow[t]{2}{*}{ Parameters } & \multicolumn{6}{|c|}{ Drying methods } \\
\hline & $\mathrm{Fr}$ & FD & MW & $\mathrm{C}-40$ & C-60 & $\mathrm{C}-80$ \\
\hline \multicolumn{7}{|l|}{ Phenolic compounds } \\
\hline TPC, mg GAE/100 g DW & $4539 \pm 57^{\mathrm{a}}$ & $3232 \pm 44^{\mathrm{b}}$ & $1975 \pm 29^{\mathrm{d}}$ & $1870 \pm 28^{\mathrm{e}}$ & $2092 \pm 28^{c}$ & $2119 \pm 23^{c}$ \\
\hline Total phenolic acids, mg CAE/100 g DW & $3214 \pm 39^{a}$ & $2904 \pm 39^{b}$ & $1624 \pm 26^{\mathrm{e}}$ & $1065 \pm 11^{\mathrm{f}}$ & $1978 \pm 24^{d}$ & $2046 \pm 26^{c}$ \\
\hline TFC, mg RE/100 g DW & $3365 \pm 28^{\mathrm{a}}$ & $1589 \pm 21^{\mathrm{b}}$ & $1443 \pm 16^{\mathrm{c}}$ & $1049 \pm 16^{\mathrm{f}}$ & $1229 \pm 29^{\mathrm{e}}$ & $1275 \pm 13^{\mathrm{d}}$ \\
\hline Total flavan-3-ol, mg CE/100 g DW & $10,713 \pm 98^{c}$ & $13,408 \pm 124^{\mathrm{b}}$ & $10,626 \pm 104^{\mathrm{c}, \mathrm{d}}$ & $9332 \pm 92^{\mathrm{e}}$ & $13,393 \pm 124^{\mathrm{b}}$ & $14,598 \pm 129^{a}$ \\
\hline Total flavonols, mg RE/100 g DW & $1172 \pm 14^{\mathrm{a}}$ & $1050 \pm 19^{b}$ & $659 \pm 17^{\mathrm{c}}$ & $479 \pm 15^{\mathrm{f}}$ & $546 \pm 17^{\mathrm{e}}$ & $619 \pm 18^{\mathrm{d}}$ \\
\hline \multicolumn{7}{|l|}{ Antioxidant activity } \\
\hline DPPH', mmol TE/100 g DW & $36 \pm 1^{\mathrm{d}}$ & $46 \pm 1^{\mathrm{c}}$ & $53 \pm 1^{\mathrm{a}}$ & $47 \pm 1^{\mathrm{b}, \mathrm{c}}$ & $48 \pm 1^{\mathrm{b}}$ & $53 \pm 1^{\mathrm{a}}$ \\
\hline $\mathrm{ABTS}^{\cdot+}, \mathrm{mmol} \mathrm{TE} / 100 \mathrm{~g} \mathrm{DW}$ & $359 \pm 9^{a}$ & $291 \pm 3^{b, c}$ & $299 \pm 8 .^{b}$ & $252 \pm 6^{\mathrm{e}}$ & $272 \pm 6^{\mathrm{d}}$ & $288 \pm 6^{\mathrm{b}, \mathrm{c}}$ \\
\hline Reducing power, mg AAE/100 g DW & $782 \pm 18^{\mathrm{d}, \mathrm{e}}$ & $1116 \pm 25^{b}$ & $1272 \pm 24^{\mathrm{a}}$ & $805 \pm 20^{\mathrm{d}}$ & $891 \pm 18^{\mathrm{c}}$ & $905 \pm 22^{\mathrm{c}}$ \\
\hline \multicolumn{7}{|l|}{ Pigments } \\
\hline Chlorophyll $a, \mathrm{mg} / \mathrm{g}$ DW & $2.44 \pm 0.02^{\mathrm{a}}$ & $1.45 \pm 0.02^{\mathrm{b}}$ & $1.04 \pm 0.03^{\mathrm{e}}$ & $1.11 \pm 0.04^{\mathrm{d}}$ & $1.29 \pm 0.06^{\mathrm{c}}$ & $1.33 \pm 0.01^{\mathrm{c}}$ \\
\hline Chlorophyll $b, \mathrm{mg} / \mathrm{g}$ DW & $0.91 \pm 0.05^{\mathrm{a}}$ & $0.78 \pm 0.04^{\mathrm{b}}$ & $0.23 \pm 0.04^{\mathrm{e},}$ & f $0.69 \pm 0.01^{\mathrm{c}}$ & $0.35 \pm 0.07^{\mathrm{d}}$ & $0.29 \pm 0.05^{\mathrm{d}, \mathrm{e}}$ \\
\hline Chlorophyll total, mg/g DW & $3.35 \pm 0.06^{\mathrm{a}}$ & $2.23 \pm 0.02^{\mathrm{b}}$ & $1.27 \pm 0.07^{\mathrm{e}}$ & $1.80 \pm 0.05^{\mathrm{c}}$ & $1.64 \pm 0.11^{\mathrm{c}, \mathrm{d}}$ & $1.62 \pm 0.04^{\mathrm{d}}$ \\
\hline Ratio $a b^{-1}$ & $2.68 \pm 0.13^{\mathrm{d}}$ & $1.86 \pm 0.10^{\mathrm{e}}$ & $4.42 \pm 0.17^{\mathrm{a}, \mathrm{t}}$ & b $1.62 \pm 0.11^{\mathrm{f}}$ & $3.70 \pm 0.03^{\mathrm{c}}$ & $4.68 \pm 0.19^{\mathrm{a}}$ \\
\hline Total carotenoids, mg/g & $0.10 \pm 0.01^{\mathrm{e}}$ & $0.15 \pm 0.01^{\mathrm{d}}$ & $0.33 \pm 0.01^{\mathrm{b}}$ & $0.28 \pm 0.01^{\mathrm{b}, \mathrm{c}}$ & $0.36 \pm 0.08^{\mathrm{b}}$ & $0.53 \pm 0.01^{\mathrm{a}}$ \\
\hline
\end{tabular}

All data are means \pm standard deviation ( $n=3$, dry basis)

$F r$ fresh, $F D$ freeze-drying, $M W$ microwave-vacuum drying, $C$ - 40 convective hot air-drying at $40{ }^{\circ} \mathrm{C}, C-60$ convective hot air-drying at $60{ }^{\circ} \mathrm{C}$, $C$-80 convective hot air-drying at $80^{\circ} \mathrm{C}, T P C$ total phenolic content, $T F C$ total flavonoid content, $D P P H$ 2,2-diphenyl-1-picrylhydraziyl radical activity, $A B T S$ 2,2'-azino-bis(3-ethylbenz-thiazoline-6-sulfonic) acid radical activity, $G A E$ gallic acid equivalent, $C A E$ caffeic acid equivalent, $R E$ rutin equivalent, $C E$ catechin equivalent, $T E$ Trolox (6-hydroxy-2,5,7,8-tetramethylchroman-2-carboxylic acid) equivalent, $A A E$ ascorbic acid equivalent, $D W$ dry weight

a,b,c... values with different superscripts in the same row are significantly different $(p \leq 0.05)$

and intensive microwave power accelerated thermal degradation of phenolic compounds. Similar trends were observed in the investigations about ginger where An et al. [34] established $29 \%$ reduction. Whereas about ginger contrasting data are also reported with increase of TPC during microwave drying [41]. MW drying resulted in a decrease of total phenolic acids in HRLP by $49 \%$. In turn, it did not have a significant effect on total flavan-3-ol content. MW drying indicated better retention of TFC and total flavonols compared to convective drying C-40 and C- 60 possibly due to a shorter drying time and, thus, reduced time for enzymatic reactions and vacuum conditions which eliminate oxygen availability.

FD was the most effective method for preserving flavonoids. Similar to other groups of phenolic compounds, flavonols were better preserved in FD samples. Low temperature and vacuum during FD reduced the activity of enzymes, resulting in the lower degradation of biologically active compounds. FD of ginger even caused increase of TPC [34]. Also for drying of apple peels, FD was reported as the most effective [1] for preserving phenolic compounds. Similar results were observed by Nunes et al. [33] in guava powder, where FD preserved $60 \%$ of TPC from fresh guava. But also contrary data are found, showing lower effectiveness of FD, for TPC preserving, namely, Kḷava et al. [36] reported twice higher TPC in hot air-dried $\left(80^{\circ} \mathrm{C}\right)$ pumpkin by-products compared to freeze-dried. Compared to fresh samples in FD apple peels, no significant changes of TFC were observed by Wolfe and Liu [1].

Thus, FD was found to be the most effective drying method for preservation of TPC, TFC, total flavonol content, and total phenolic acid content.

\section{Profile of individual phenolic compounds}

Totally, 14 individual phenolic compounds were determined in the studied HRLP samples (Table 2). Specifically, 12 compounds in fresh pomace, 11 in each of FD, MW and C-80 samples, and 10 in each of C- 40 and C-60 were noted. Gallic acid and 3-hydroxycinnamic acid were detected only in the fresh HRLP $0.17 \pm 0.01 \mathrm{mg} / 100 \mathrm{~g}$ DW and $0.09 \pm 0.00 \mathrm{mg} / 100 \mathrm{~g} \mathrm{DW}$, respectively. But, 5-hydroxybenzoic acid was detected only in the FD sample of HRLP $(1.17 \pm 0.06 \mathrm{mg} / 100 \mathrm{~g} \mathrm{DW})$. Significant quantities of rutin were present in all samples. The variation of rutin content was drying type-dependent. Its content decreased in MW and FD by $31 \%$ and $19 \%$, respectively. Conversely, convective drying at $80{ }^{\circ} \mathrm{C}$ demonstrated rutin content increase by $12 \%$. Possibly covalent bonds could be broken down and 
Table 2 Individual phenolic compounds and organic acid profile (mg/100 g DW) in horseradish leaves pomace (HRLP) dried by different methods

\begin{tabular}{|c|c|c|c|c|c|c|}
\hline \multirow[t]{2}{*}{ Parameters } & \multicolumn{6}{|l|}{ Drying methods } \\
\hline & $\mathrm{Fr}$ & FD & MW & C-40 & C-60 & $\mathrm{C}-80$ \\
\hline \multicolumn{7}{|c|}{ Individual phenolic compounds } \\
\hline$(+)$-Catechin & $0.19 \pm 0.01^{\mathrm{f}}$ & $2.85 \pm 0.14^{\mathrm{d}}$ & $2.40 \pm 0.12^{\mathrm{e}}$ & $5.66 \pm 0.28^{\mathrm{c}}$ & $8.31 \pm 0.42^{\mathrm{b}}$ & $12.02 \pm 0.60^{\mathrm{a}}$ \\
\hline 4-Hydroxybenzoic acid & $0.26 \pm 0.01^{\mathrm{b}, \mathrm{c}}$ & $0.46 \pm 0.02^{\mathrm{a}}$ & $0.23 \pm 0.01^{\mathrm{d}}$ & $0.24 \pm 0.01^{\mathrm{c}, \mathrm{d}}$ & $0.26 \pm 0.01^{\mathrm{b}, \mathrm{c}}$ & $0.28 \pm 0.01^{\mathrm{b}}$ \\
\hline Chlorogenic acid & $0.67 \pm 0.03^{\mathrm{c}}$ & $1.00 \pm 0.05^{\mathrm{a}}$ & $0.54 \pm 0.03^{\mathrm{e}}$ & $0.56 \pm 0.02^{\mathrm{d}, \mathrm{e}}$ & $0.61 \pm 0.03^{\mathrm{c}, \mathrm{d}}$ & $0.81 \pm 0.04^{\mathrm{b}}$ \\
\hline (-)-Epicatechin & $16.14 \pm 0.81^{\mathrm{b}}$ & $18.12 \pm 0.91^{\mathrm{a}}$ & $10.02 \pm 0.50^{\mathrm{d}}$ & $7.93 \pm 0.40^{f}$ & $8.81 \pm 0.44^{\mathrm{e}}$ & $13.89 \pm 0.69^{c}$ \\
\hline Syringic acid & ND & $2.09 \pm 0.10^{\mathrm{a}}$ & $1.00 \pm 0.05^{\mathrm{c}}$ & $0.34 \pm 0.02^{\mathrm{e}}$ & $0.60 \pm 0.03^{\mathrm{d}}$ & $1.41 \pm 0.07^{\mathrm{b}}$ \\
\hline p-Coumaric acid & $0.58 \pm 0.03^{\mathrm{a}}$ & $0.47 \pm 0.02^{\mathrm{b}}$ & $0.23 \pm 0.01^{\mathrm{c}}$ & $0.01 \pm 0.00^{f}$ & $0.03 \pm 0.00^{\mathrm{e}}$ & $0.04 \pm 0.00^{\mathrm{d}}$ \\
\hline Sinapic acid & $0.12 \pm 0.01^{\mathrm{e}}$ & ND & $1.48 \pm 0.07^{\mathrm{b} . c}$ & $1.28 \pm 0.06^{\mathrm{d}}$ & $1.52 \pm 0.08^{\mathrm{b}}$ & $2.80 \pm 0.14^{\mathrm{a}}$ \\
\hline $\mathrm{t}$-Ferulic acid & $0.23 \pm 0.01^{\mathrm{b}}$ & $0.32 \pm 0.02^{\mathrm{a}}$ & $0.05 \pm 0.00^{\mathrm{c}}$ & $\mathrm{ND}$ & $\mathrm{ND}$ & $0.02 \pm 0.00^{\mathrm{d}}$ \\
\hline 2-Hydroxycinnamic acid & $0.28 \pm 0.01^{\mathrm{e}}$ & $1.83 \pm 0.09^{\mathrm{b}}$ & $1.77 \pm 0.09^{\mathrm{b}, \mathrm{c}}$ & $1.43 \pm 0.07^{\mathrm{d}}$ & $1.81 \pm 0.09^{\mathrm{b}}$ & $2.85 \pm 0.14^{\mathrm{a}}$ \\
\hline Rutin & $3231.07 \pm 161.55^{\mathrm{b}}$ & $2598.89 \pm 129.94^{\mathrm{d}}$ & $2212.90 \pm 110.64^{\mathrm{e}}$ & $2909.07 \pm 145.45^{\mathrm{c}}$ & $3294.70 \pm 164.74^{b}$ & $3649.39 \pm 182.47^{\mathrm{a}}$ \\
\hline Luteolin & $1.28 \pm 0.06^{\mathrm{f}}$ & $3.62 \pm 0.18^{\mathrm{a}}$ & $1.96 \pm 0.10^{\mathrm{c}}$ & $1.55 \pm 0.08^{\mathrm{e}}$ & $1.76 \pm 0.09^{\mathrm{d}}$ & $2.72 \pm 0.14^{\mathrm{b}}$ \\
\hline Other* & $0.26 \pm 0.01^{\mathrm{b}}$ & $1.17 \pm 0.06^{\mathrm{a}}$ & ND & ND & ND & ND \\
\hline \multicolumn{7}{|l|}{ Organic acids } \\
\hline Oxalic acid & $44.4 \pm 2.2^{\mathrm{c}}$ & $178.1 \pm 8.9^{\mathrm{a}}$ & $83.2 \pm 4.2^{\mathrm{b}}$ & $86.1 \pm 4.3^{\mathrm{b}}$ & $86.9 \pm 4.4^{\mathrm{b}}$ & $87.8 \pm 4.4^{\mathrm{b}}$ \\
\hline Quinic acid & $197.7 \pm 10.0^{\mathrm{a}}$ & $26.4 \pm 1.3^{\mathrm{d}}$ & $149.6 \pm 7.6^{\mathrm{b}}$ & $132.8 \pm 6.8^{c}$ & $133.6 \pm 6.8^{c}$ & $134.7 \pm 6.8^{\mathrm{c}}$ \\
\hline Malic acid & $135.0 \pm 6.7^{\mathrm{c}}$ & $16.7 \pm 0.8^{\mathrm{d}}$ & $202.3 \pm 10.1^{\mathrm{a}}$ & $164.9 \pm 8.2^{\mathrm{b}}$ & $166.2 \pm 8.3^{b}$ & $167.2 \pm 8.3^{\mathrm{b}}$ \\
\hline Ascorbic acid & $7.8 \pm 0.4^{\mathrm{a}}$ & $3.6 \pm 0.2^{\mathrm{b}}$ & $0.6 \pm 0.0^{c}$ & $\mathrm{ND}$ & ND & ND \\
\hline Citric acid & $175.0 \pm 8.2^{\mathrm{a}}$ & $150.4 \pm 7.0^{\mathrm{b}, \mathrm{c}}$ & $154.7 \pm 7.2^{\mathrm{b}}$ & $153.4 \pm 7.2^{\mathrm{b}}$ & $153.7 \pm 7.2^{\mathrm{b}}$ & $154.0 \pm 7.2^{\mathrm{b}}$ \\
\hline Fumaric acid & $4.9 \pm 0.2^{\mathrm{b}}$ & $9.6 \pm 0.4^{\mathrm{a}}$ & $1.6 \pm 0.1^{\mathrm{e}}$ & $3.1 \pm 0.1^{\mathrm{d}}$ & $3.4 \pm 0.2^{\mathrm{c}, \mathrm{d}}$ & $3.6 \pm 0.2^{\mathrm{c}}$ \\
\hline Succinic acid & $135.1 \pm 6.8^{\mathrm{b}}$ & $50.1 \pm 2.5^{\mathrm{d}}$ & $181.3 \pm 9.2^{\mathrm{a}}$ & $66.9 \pm 3.4^{\mathrm{c}}$ & $67.8 \pm 3.4^{\mathrm{c}}$ & $68.5 \pm 3.5^{\mathrm{c}}$ \\
\hline Other** & $45.7 \pm 2.4^{\mathrm{a}}$ & ND & ND & ND & ND & ND \\
\hline
\end{tabular}

All data are means \pm standard deviation ( $n=3$, dry basis)

$\mathrm{Fr}$ fresh, $F D$ freeze-drying, $M W$ microwave-vacuum drying, $C$ - 40 convective hot air-drying at $40{ }^{\circ} \mathrm{C}, C-60$ convective hot air-drying at $60{ }^{\circ} \mathrm{C}$, $C$-80 convective hot air-drying at $80{ }^{\circ} \mathrm{C}, D W$ dry weight, $N D$ not detected.

*Gallic acid, 3.5-dihydroxybenzoic acid, 3-hydroxycinnamic acid

**Tartaric acid, lactic acid, acetic acid

a, b, $\ldots=$ values with different superscripts in the same row are significantly different $(p \leq 0.05)$

phytochemicals are released from chromoplasts by microwave energy, resulting in an increment in the concentration in the final product [42]. Inconsistencies between spectrophotometrically determined total content of phenolic acids and individual phenolic acids determined by HPLC have been noticed. This possibly is because of the methodology used. At this stage, results are inconclusive and further research is needed by including in HPLC analysis of other phenolic acids and/or improving extraction procedure for spectrophotometric analysis.

(-)-Epicatechin content after FD increased by $12 \%$, but all other drying methods caused its decrease by $14-50 \%$ compared to fresh HRLP.

Aguilera et al. [43] described that the increase in phenolics during FD may be related to the changes in plant cell structure due to ice crystal formation, which can cause degradation of cells. In the plant cell, bioactive compounds are protected from the surrounding environment; therefore, for compound extraction are required specific physical and chemical conditions to release them from the matrix. For example, ferulic acid is esterified and bound to specific polysaccharides, and then, it is possible to extract only $0.5-2 \%$. In the case of free compounds, extraction rate can reach higher level depending on the used method [44].

HPLC analysis of individual phenolic compounds revealed that total amount of phenolic compounds increased by $13 \%$ after convective drying at $80^{\circ} \mathrm{C}$ with shorter drying time, but it decreased by $31 \%$ in MW drying. For the effective preservation of 4-hydroxybenzoic, syringic, ferulic and chlorogenic acids, epicatechin and luteolin in HRLP FD may be recommended, but for the preservation of sinapic acid, 2-hydroxycinnamic acid, (+)-catechin and rutin, convective air-drying at $80{ }^{\circ} \mathrm{C}$ temperature may be recommended. 


\section{Effect of drying method on antioxidant activity of HRLP}

The highest $\mathrm{DPPH}^{\cdot}$ antioxidant activity among studied products was in the samples dried in the convective dryer at $80{ }^{\circ} \mathrm{C}$ (Table 1), while the microwave-vacuum-dried samples exhibited the highest $\mathrm{ABTS}^{\circ}{ }^{-}$antioxidant activity. Both microwave energy and high temperature may cause cell structure damage resulting in the release of the compounds, which may be hydrogen atom or electron donors, resulting in free radical-scavenging activity. HRLP dried at $80{ }^{\circ} \mathrm{C}$ contained the highest amount of rutin and high content of chlorogenic acid, which according to Braham et al. [45] may be associated with significant scavenging properties of plant extracts. Strong correlation between ABTS ${ }^{+}$ and total flavonoid content (TFC), $r=0.935$ in HRLP was observed. Overall, $\mathrm{ABTS}^{\cdot+}$ values closely correlated with TPC $(r=0.856)$ and total flavonol content $(r=0.818)$.

For evaluation of antioxidant activity, it is advised to use several approaches to get a broader overview of activity. In the current investigation, three assays were tested as $\mathrm{DPPH}^{*}, \mathrm{ABTS}^{\cdot+}$, and reducing power. Their reactivity differs due to the type of free radicals used for the evaluation of antioxidant properties of extracts. ABTS method is based on ABTS cation radical formation and inhibition. It uses intensely coloured $\mathrm{ABTS}^{-+}$cation radicals, which accept hydrogen electrons or atoms from antioxidants [46]. This method is suitable for the detection of both hydrophilic and lipophilic antioxidants. The DPPH method is based on the measurement of the ability of antioxidants to donate hydrogen atom, thus, reducing free radicals in the solution. In this test, the reaction of product with $\mathrm{DPPH}^{*}$ reacts with sample in aqueous and nonpolar organic solvents. Each test uses different free radicals and reactions, which depend on the compounds present in the product; therefore, there can be observed the differences between antioxidant capacities determined by different methods. Similar to our study, for the drying of pumpkin by-products, as the most effective method for preserving the antioxidant activity (both with $\mathrm{DPPH}^{\cdot}$ and $\mathrm{ABTS}^{-+}$assays), Klava et al. [36] suggested drying at $80^{\circ} \mathrm{C}$. Contrary to the current results, for the drying of quince fruits [4] and jujube fruits [9], the highest antioxidant activity (using ABTS $^{\cdot+}$ assay) was achieved in FD samples. For obtaining guava powder with the highest antioxidant activity, a forced air circulation oven at $55^{\circ} \mathrm{C}$ for $22 \mathrm{~h}$ was proposed [33].

Dried horseradish leaves pomace samples exhibited higher reducing power compared to the fresh pomace. Reducing power for MW-dried pomace was by $62 \%$, but for FD by $42 \%$ higher than in fresh pomace dry matter.

Principal component analysis (PCA) showed that PC1 explained $49.53 \%$ of total variances (Fig. 3). Cumulative input from the first and second principal component reached $72.36 \%$.

PCA allowed allocating the studied samples in separate groups. Fresh HRLP (Fr) is characterised by higher content of TPC, total phenolic acids, TFC, total flavonols, $p$-Coumaric acid and ABTS ${ }^{-+}$. Separate group is formed by
Fig. 3 Principal component analysis (PCA) plot of data from phenolic compounds and antioxidant activity of horseradish leaves pomace (HRLP) processed using different drying methods (TPC total phenolic content, TFC total flavonoid content, $D P P H$ 2,2-diphenyl1-picrylhydraziyl radical activity, ABTS 2,2'-azino-bis(3ethylbenz-thiazoline-6-sulfonic) acid radical activity)

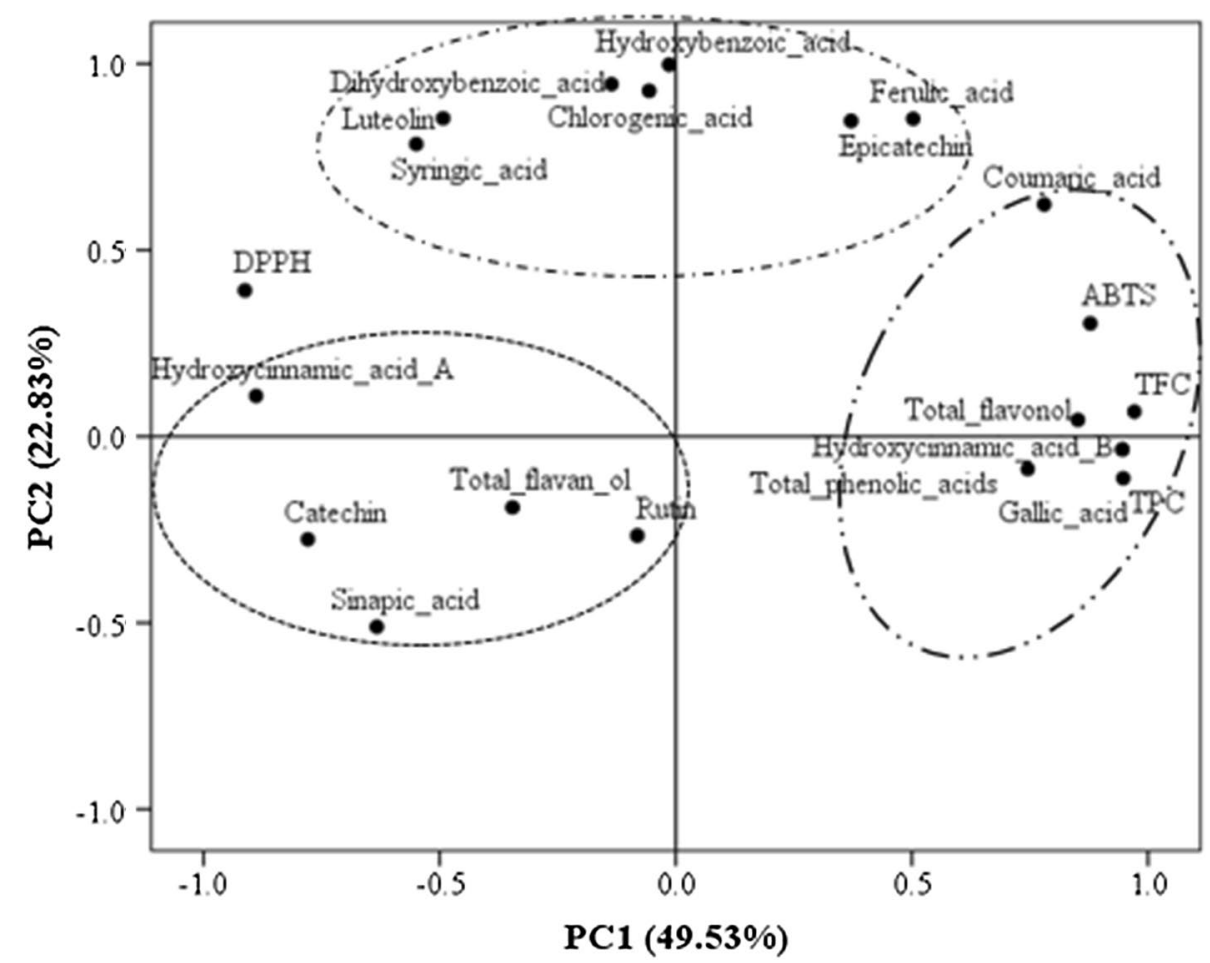


six individual phenolic compounds, such as 4-hydroxybenzoic acid, chlorogenic acid, (-)-epicatechin, syringic acid, $\mathrm{t}$-ferulic acid, and luteolin, which were found to have higher content in FD samples compared to other studied products. MW drying can be suggested for better preservation of antioxidant activities in HRLP. Hot air-dried samples form another group, which is characterised by higher content of total flavan-3-ol, (+) catechin, sinapic acid, 2-hydroxycinnamic acid and rutin. Also, $\mathrm{DPPH}^{*}$ activity is well preserved in the convective dried HRLP.

Differences in antioxidant activities between MW, C-80 and C-40 dried samples could be due to polyphenol oxidases. These enzymes catalyse the oxidation of phenols to quinones with subsequent nonenzymatic rapid polymerization [36]. Thus, possibly, there were better conditions for enzymatic reactions in C-40 and C-60 samples, resulting in lower phenolic content and lower antioxidant activity.

\section{Organic acid profile}

Among organic acids in fresh HRLP, the highest content was for quinic, citric, succinic and malic acids (Table 2). Depending on the organic acid type and the dehydration method, acid content varied significantly after drying. The increase of oxalic acid content was affected by drying method. Thus, its content in FD sample was fourfold higher in all other dried samples and it was doubled compared to the fresh sample dry matter. Priecina et al. [26] observed contrary trend-oxalic acid content decreased when drying celery roots in the convective or MW driers.

Drying significantly reduced quinic acid content in HRLP by $87 \%$ (FD), $32 \%$ (C-80), and 24\% (MW), respectively. Priecina et al. [26] revealed that quinic acid was found only in few dried celery root samples after blanching. Change in quinic acid content possibly resulted from redistribution of plant resources towards other shikimic acid pathway products [47].

Despite the small ascorbic acid content in fresh HRLP, it demonstrated similar trend as described by Priecina et al. [26] in dried celery root. In the drying process of pomace, ascorbic acid significantly degraded and its content after FD treatment decreased by $54 \%$, but MW reduced it by $92 \%$. The reason for ascorbic acid content decrease and oxalate increase may be oxidative degradation pathway [48].

Citric acid content also decreased by $12-14 \%$ as a result of HRLP drying, which possibly is caused by thermal decomposition as described by Wyrzykowski et al. [49].

Fumaric acid content in HRLP increased by $95 \%$ after $\mathrm{FD}$, whereas in the case of increased treatment temperature, such as MW and C-80, fumaric acid content decreased by $68 \%$ and $28 \%$, respectively.

Succinic acid content in HRLP increased by $34 \%$ after MW drying, whereas in C-80 and FD samples, succinic acid content decreased by $63 \%$ and $49 \%$, respectively, which had the same trend as Priecina et al. [26] confirmed in celery root.

Fresh HRLP contained $45.7 \pm 2.4 \mathrm{mg} / 100 \mathrm{~g}$ DW tartaric acid, which was completely degraded and it was not found in any of the dried HRLP samples.

The most effective preservation of malic acid was observed in MW-dried HRLP, while oxalic and fumaric acids were the most retained in FD samples.

Overall, the best method for organic acid preservation in HRLP was MW drying. Total content of organic acids decreased in C- 80 by $17 \%$, but in FD even by $42 \%$.

\section{Chlorophylls and total carotenoids}

The content of chlorophyll $a$ observed in HRLP $(0.80 \pm 0.01 \mathrm{mg} / \mathrm{g} \mathrm{FW})$ was higher than its content in peppermint leaves of different varieties $(0.321$ till $0.849 \mathrm{mg} / \mathrm{g})$ [27] But, it was smaller than the values reported for the leaves of peanut (Arachis hypogaea L.) $(1.606 \mathrm{mg} / \mathrm{g})[50]$ or the leaves of Indian mustard (Brassica juncea L.) $(11.30 \mathrm{mg} / \mathrm{g})$ [51].

Chlorophyll $b$ content in HRLP was $0.26 \pm 0.01 \mathrm{mg} / \mathrm{g}$ $\mathrm{FW}$, being higher than in peppermint leaves $(0.066$ till $0.179 \mathrm{mg} / \mathrm{g}$ ) reported by Straumite et al. [27] and much lower than in the leaves of peanut (Arachis hypogaea $\mathrm{L}$.) $(0.474 \mathrm{mg} / \mathrm{g})[51]$ or the Indian mustard (Brassica juncea L.) leaves (5.79 mg/g FW) [51].

The drying method had a significant effect $(p \leq 0.05)$ on all studied pigment types (Table 1). Drying reduced chlorophyll content in HRLP. Chlorophyll $a$ content was reduced by $40-57 \%$, but chlorophyll $b$ by $14-74 \%$ of DW depending on the drying method. According to Di Cesare et al. [52], chlorophyll $b$ is more stable in pheophytinization reactions compared to chlorophyll $a$ [53]. Other researchers also reported the effect of processing temperature, presence of oxygen, enzyme activity and other factors on chlorophyll stability [54].

Chlorophyll degradation may occur via chemical, biochemical or enzymatic reactions. The most effective method for both chlorophyll $a$ and chlorophyll $b$ preservation proved to be FD, where products are not exposed to high temperatures and the process takes place under vacuum, which reduces the oxygen availability and the rate of enzymatic reactions. In all other studied drying methods, there was increased temperature, which may induce chemical reactions resulting in the replacement of manganese ion in porphyrin ring and the formation of pheophytin. During thermal treatment may occur decarbomethoxylation, which induces other reactions until the formation of pyropheophytin [55].

Unfortunately, even the application of low temperature during drying did not guarantee high chlorophyll content $[51,56]$. It is related to the longer drying time and heat 
transfer through the surface, which were confirmed in the current study, where chlorophyll $a$ content at $40{ }^{\circ} \mathrm{C}$ decreased by $54 \%$, but at $80{ }^{\circ} \mathrm{C}$, it decreased only by $45 \%$ compared to fresh HRLP. Longer drying time and lower temperature allow oxidative enzyme activity (lipoxygenase, chlorophyll oxidase, and peroxidase), which contributes to chlorophyll loss and formation of oxidized chlorophyll catabolites [57].

The total carotenoid in HRLP $(0.10 \pm 0.01 \mathrm{mg} / \mathrm{g}$ DW $)$ was similar to the value in the leaves of Mentha spicata varieties (0.04-0.10 mg/100 g) [27] or pak choi (Brassica rapa ssp. chinensis) sprouts (70-500 ng/mg DW) [58].

In the current study, total carotenoid content significantly increased irrespective of applied drying method and the highest content was found in C-80 samples. When drying at $80^{\circ} \mathrm{C}$, total carotenoid content in pomace was by $86 \%$ bigger compared to the pomace dried at $40{ }^{\circ} \mathrm{C}$. Data from the study of Multari et al. [38] show similar trend that moderate heat improved the extraction efficiency from quinoa seeds, peaking at $60{ }^{\circ} \mathrm{C}$. According to Kotíková et al. [59], moderate heat might have caused the disruption of the carotenoid protein complexes and the inactivation of carotenoid-oxidizing enzymes prevented the degradation of pigments. Many studies provided contradictory results, indicating thermal degradation of carotenoids [60-62]; however, their data revealed that the difference in the type of food matrix, carotenoid structure, and the type of processing had a significant effect.

\section{Effect of drying on volatile compounds in HRLP}

In HRLP totally, 49 volatiles were identified. Table 3 shows the major volatile compounds, while compounds whose content did not exceed $2 \%$ are combined under others. The main volatile in fresh HRLP was allyl isothiocyanate (23.39\%), which is confirmed also by Petrović et al. [62] and Kroener and Buettner [63]. Allyl isothiocyanate gives pungent, mustard-like, horseradish-like, onion-like odour notes [63]. The following major volatile compounds, such as 5-methylthiopentyl isothiocyanate (berteroin) and 6-methylthiohexyl isothiocyanate (lesquerellin) that ranged between $55.0-59.0 \%$ and $34.1-36.4 \%$, respectively, were detected by Petrović et al. [62] in a wild plant Armoracia macrocarpa. The major volatile compounds in dried HRLP were 3-butenenitrile, acetic acid, and benzyl alcohol. Qualitative and quantitative profile of volatiles is similar to phenolic compounds affected by genotype, growing conditions, and weather conditions [32], which are confirmed also by other researchers [33].

The drying methods had various effects on the volatile compositions in HRLP. In convective drying, at increased temperature and reduced drying time, the content of pentanal decreased, simultaneously, with the increased content of acetic acid and benzaldehyde. Some studies demonstrated that the formation of new volatile compounds has positive correlation with drying time as well as temperature [5]. Thus, air-drying of oregano significantly decreased the content of volatile compounds [13].

Bigger volatile compound losses from HRLP were observed in convective (hot air) drying compared to FD or MW drying. This fact may be related to the increased volatile compound evaporation due to longer drying time. Szumny et al. [64] observed the biggest loss of volatiles from rosemary in the MW-dried samples.

Several compounds (such as carbonyl disulphide, alphaphellandrene, and others) were detected exceptionally in fresh HRLP, which may indicate their volatility.

Overall, better preservation of volatile compounds in HRLP FD can be recommended.

PCA of volatile compounds (Fig. 4) indicated that PC1 explained $43.61 \%$ of total variances. Cumulative contribution of PC1 and PC2 reached $66.13 \%$.

According to PCA of volatile compounds, FR sample can be allocated in a separate group similar to PCA of phenolics and antioxidant activities. Fr pomace contains such isothiocyanates as allyl isothiocyanate and butyl isothiocyanate, which were completely lost in the drying process along with some other volatiles. Loss of volatiles occurs at various rates and to various extent because they degrade due to the activity of enzymes (mirosynase and other), presence of air oxygen or metal ions. Thus, only fresh HRLP is characterised by the presence of the following volatile compounds, which give specific aroma to the products: isothiocyanates (strong, pungent, mustard, green), allantoic acid (garlic like), carbonyl sulphide (sulfide like), carbonyl disulphide (aromatic), $\alpha$-phelanderene (citrus, herbal, terpene, green, woody, peppery) and $\beta$-phelanderene (mint, terpentine).

Despite large losses of volatile compounds, among all the dried HRLP, only FD sample retained some amounts of such compounds as 2-nitro ethanol (woody), 2-methyl2-propenenitrile (bitter almond), and (Z)-2-hexen-1-ol (green, cortex, leafy, green, bean, nasturtium, herbal, soapy, aldehydic, narcissus, phenolic). Compared to other samples, FD pomace contained a higher amount of 3-butenenitrile (onion odour), but benzyl alcohol and benzaldehyde were in the lowest concentration.

The samples dried at lower temperatures (C-40 and C-60), which required a longer time to reach final moisture, are allocated in a separate group according to PCA. These samples contained such volatile compounds as carbondioxide (odourless), pentanal (fermented, bready, fruity, nutty, berry), 2-ethyl-1-hexanal (citrus, fresh, floral, oily, sweet), and benzyl alcohol (floral, rose, phenolic, balsamic), which may be formed in the degradation reactions of other compounds. 
Table 3 Volatile fractions in horseradish leaves pomace (HRLP)

\begin{tabular}{|c|c|c|c|c|c|c|c|c|c|}
\hline \multirow[t]{2}{*}{ Nr.p.k } & \multirow[t]{2}{*}{ R.T (min) } & \multirow[t]{2}{*}{ Compounds } & \multirow[t]{2}{*}{ Flavor/odor description } & \multicolumn{6}{|c|}{ Fraction, $\%$} \\
\hline & & & & $\mathrm{Fr}$ & FD & MW & $\mathrm{C}-40$ & C-60 & C-80 \\
\hline 1 & 4.02 & Carboondioxide & /odorless ${ }^{\mathrm{a}}$ & ND & 2.32 & 4.43 & 5.70 & 6.28 & 3.73 \\
\hline 2 & 4.03 & Allantoic acid & Garlic $^{\mathrm{b}}$ & 2.42 & ND & ND & ND & ND & ND \\
\hline 3 & 4.04 & Carbonyl sulfide & /sulfide like ${ }^{\mathrm{a}}$ & 2.02 & ND & ND & ND & ND & ND \\
\hline 4 & 4.96 & Carbonyl disulfide & -sweet and aromatic ${ }^{c}$ & 11.11 & ND & ND & ND & ND & ND \\
\hline 5 & 6.01 & Acetone & /solvent ethereal apple pear ${ }^{\mathrm{a}}$ & 13.15 & ND & 5.44 & 21.39 & 16.13 & 13.16 \\
\hline 6 & 6.05 & Manganese (II) acetate & n.i & ND & 2.28 & ND & ND & ND & 4.14 \\
\hline 7 & 9.01 & Ethylalcohol & /strong alcoholic ethereal medical ${ }^{\mathrm{a}}$ & 8.47 & 7.40 & 18.28 & 11.08 & 9.83 & 7.00 \\
\hline 8 & 9.03 & Methane, nitroso & -mild fruity & ND & ND & 2.46 & ND & ND & ND \\
\hline 9 & 9.06 & Ethanal, 2-nitro & /woody ${ }^{\mathrm{a}}$ & ND & 2.16 & ND & ND & ND & ND \\
\hline 10 & 10.44 & Pentanal & $\begin{array}{l}\text { winey, fermented, bready, cocoa chocolate notes/ } \\
\text { fermented bready fruity nutty berry }{ }^{\mathrm{a}}\end{array}$ & 0.51 & 1.36 & ND & 2.94 & 1.76 & 0.92 \\
\hline 11 & 13.86 & Hexanal & $\begin{array}{l}\text { green, woody, vegetative, apple, grassy, citrus and } \\
\text { orange with a fresh, lingering aftertaste/fresh } \\
\text { green fatty aldehydic grass leafy fruity sweaty }\end{array}$ & 2.38 & 2.39 & 1.65 & ND & ND & 0.89 \\
\hline 12 & 14.51 & 2-Propenenitrile, 2-methyl- & -bitter almond & ND & 2.45 & ND & ND & ND & ND \\
\hline 13 & 14.53 & 2-Butenenitrile & n.i & ND & 3.41 & 4.00 & ND & ND & ND \\
\hline 14 & 16.27 & $\alpha$-Phellandrene & $\begin{array}{l}\text { terpenic, citrus lime with a fresh green note/citrus } \\
\text { herbal terpene green woody peppery }\end{array}$ & 8.31 & ND & ND & ND & ND & ND \\
\hline 15 & 16.47 & 2-Penten-1-ol, (Z)- & $\begin{array}{l}\text { ethereal green nasturtium spicy mustard horserad- } \\
\text { ish/green phenolic nasturtium ethereal medicinal } \\
\text { aldehydic cherry narcissus metallic fruity }{ }^{\mathrm{a}}\end{array}$ & ND & 4.86 & ND & ND & ND & 3.44 \\
\hline 16 & 16.49 & 2-Hexen-1-ol, (Z) & $\begin{array}{l}\text { green nasturtium vegetable herbal tomato leaf } \\
\text { potato fusel weedy/green cortex leafy green bean } \\
\text { nasturtium herbal soapy aldehydic narcissus } \\
\text { phenolic }^{\mathrm{a}}\end{array}$ & ND & 5.73 & ND & ND & ND & ND \\
\hline 17 & 17.25 & 3-Butenenitrile & -onion & ND & 39.54 & 3.75 & ND & ND & 3.46 \\
\hline 18 & 17.64 & $\beta$-phelandrene & $/$ mint terpentine $^{\mathrm{a}}$ & 4.47 & ND & ND & ND & ND & ND \\
\hline 19 & 19.66 & Butyl isothiocyanate & /sulfury pungent green ${ }^{\mathrm{a}}$ & 3.74 & ND & ND & ND & ND & ND \\
\hline 20 & 22.17 & Allyl isothiocyanate & $\begin{array}{l}\text { mustard horseradish wasabi/strong pungent } \\
\text { mustard }^{\mathrm{a}}\end{array}$ & 23.39 & 9.42 & ND & ND & ND & 5.78 \\
\hline 21 & 24.41 & Acetic acid & $\begin{array}{l}\text { pungent sour overripe fruit/sharp pungent sour } \\
\text { vinegar }^{\mathrm{a}}\end{array}$ & ND & 5.60 & 22.92 & 17.11 & 18.08 & 16.23 \\
\hline 22 & 24.87 & 1-Hexanal, 2-ethyl & sweet fatty fruity/citrus fresh floral oily sweet ${ }^{\mathrm{a}}$ & 1.59 & ND & 1.32 & 2.04 & 1.92 & ND \\
\hline 23 & 25.76 & $\begin{array}{l}\text { 3,6-Dimethyl- } \\
\text { 2,3,3a,4,5,7a-hexahyd- } \\
\text { robenzofuran }\end{array}$ & herbal dill ${ }^{\mathrm{a}}$ & 4.71 & ND & ND & ND & ND & ND \\
\hline 24 & 26.11 & Benzaldehyde & $\begin{array}{l}\text { sweet, oily, almond, cherry, nutty and woody/ } \\
\text { strong sharp sweet bitter almond cherry }{ }^{\mathrm{a}}\end{array}$ & 4.54 & 2.61 & 10.79 & 10.10 & 10.36 & 13.00 \\
\hline \multirow[t]{2}{*}{25} & 32.16 & Benzyl alcohol & $\begin{array}{l}\text { chemical fruity cherry almond balsamic bitter/ } \\
\text { floral rose phenolic balsamic }\end{array}$ & 3.48 & 2.28 & 11.05 & 27.8 & 35.64 & 13.55 \\
\hline & & Other & & 5.72 & 6.20 & 13.89 & 1.81 & ND & 14.70 \\
\hline
\end{tabular}

$N D$ not detected, fresh (Fr), freeze-drying (FD), microwave-vacuum drying (MW), convective hot air-drying at $40{ }^{\circ} \mathrm{C}(\mathrm{C}-40)$, convective hot airdrying at $60{ }^{\circ} \mathrm{C}(\mathrm{C}-60)$, convective hot air-drying at $80{ }^{\circ} \mathrm{C}(\mathrm{C}-80)$

${ }^{a}$ From The Good Scents Company Information System

${ }^{\mathrm{b}}$ Oxford Dictionary of Biochemistry and Molecular Biology (2006)

${ }^{\mathrm{c}}$ Air quality guidelines WHO (2000) Ch.5. Carbon disulfide

\section{Conclusion}

Fresh horseradish leaves pomace contained significantly higher amounts of TPC, TFC, total flavonol content and total phenolic acid content compared to dried pomace. Only the content of flavan-3-ols increased after drying. In the drying process, gallic acid and 3-hydroxycinnamic acid were totally degraded. Rutin content increased in horseradish 
Fig. 4 Principal component analysis (PCA) plot of data from volatile compounds of horseradish leaves pomace (HRLP) from different drying methods $(\mathrm{Fr}$ fresh, $F D$ freeze-dried, $M W$ microwave-vacuum dried, $C$ - 40 convective dried at $40^{\circ} \mathrm{C}, \mathrm{C}-60$ convective dried at $60^{\circ} \mathrm{C}, \mathrm{C}-80$ convective dried at $80^{\circ} \mathrm{C}$ )

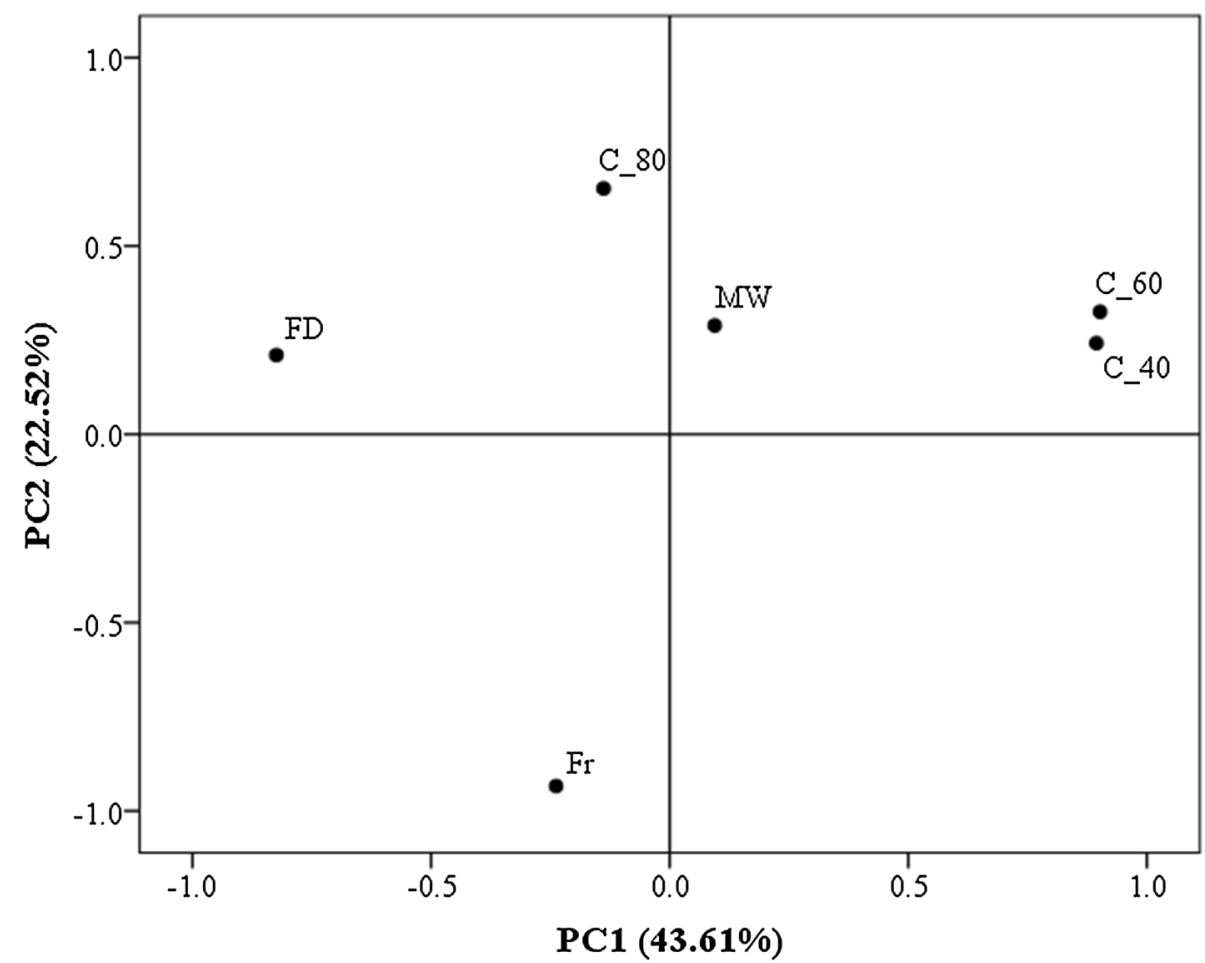

leaves pomace after convective hot air-drying at $80^{\circ} \mathrm{C}$. The highest DPPH ${ }^{\circ}$ antioxidant activity was in the samples dried in the convective dryer at $80^{\circ} \mathrm{C}$, but $\mathrm{ABTS}^{\circ+}$ antioxidant activity was in the microwave-vacuum-dried pomace. The major volatile compound in fresh pomace was allyl isothiocyanate; however, it was not found in any of the dried samples. Dried horseradish leaves pomace has the potential as the food ingredient containing valuable bioactive compounds and possessing antioxidant activity.

Drying can be used to extend the shelf life of horseradish leaves pomace. Overall, the most effective drying technology for retaining phenolic compounds and volatile compounds in horseradish leaves pomace is freeze-drying. In the case of convective drying, the majority of the studied bioactives are better preserved when drying at higher temperatures and shorter time.

Funding This study was financially supported by the ERDF Post-doctoral Research Support Program (project Nr.1.1.1.2/16/I/001) Research application "The changes of horseradish biologically active compounds and their bioavailability in an in vitro model of the human gastrointestinal tract as a result of technological processes" (Nr.1.1.1.2./ VIAA/1/16/187).

\section{Compliance with ethical standards}

Conflict of interest The authors declare no conflict of interest.

Ethical approval This study does not contain any studies with human or animal subjects.
Open Access This article is licensed under a Creative Commons Attribution 4.0 International License, which permits use, sharing, adaptation, distribution and reproduction in any medium or format, as long as you give appropriate credit to the original author(s) and the source, provide a link to the Creative Commons licence, and indicate if changes were made. The images or other third party material in this article are included in the article's Creative Commons licence, unless indicated otherwise in a credit line to the material. If material is not included in the article's Creative Commons licence and your intended use is not permitted by statutory regulation or exceeds the permitted use, you will need to obtain permission directly from the copyright holder. To view a copy of this licence, visit http://creativecommons.org/licenses/by/4.0/.

\section{References}

1. Wolfe KL, Liu RH (2003) Apple peels as a value-added food ingredient. J Agric Food Chem 51:1676-1683. https://doi. org/10.1021/jf025916z

2. Garcia-Garcia G, Stone J, Rahimifard S (2019) Opportunities for waste valorisation in the food industry - a case study with four UK food manufacturers. J Clean Prod. https://doi.org/10.1016/j. jclepro.2018.11.269

3. Kayacan S, Karasu S, Akman PK et al (2020) Effect of different drying methods on total bioactive compounds, phenolic profile, in vitro bioaccessibility of phenolic and HMF formation of persimmon. LWT 118:108830. https://doi.org/10.1016/j. lwt.2019.108830

4. Szychowski PJ, Lech K, Sendra-Nadal E et al (2018) Kinetics, biocompounds, antioxidant activity, and sensory attributes of quinces as affected by drying method. Food Chem 255:157-164. https:// doi.org/10.1016/j.foodchem.2018.02.075

5. Sellami IH, Wannes WA, Bettaieb I et al (2011) Qualitative and quantitative changes in the essential oil of Laurus nobilis L. leaves 
as affected by different drying methods. Food Chem 126:691-697. https://doi.org/10.1016/j.foodchem.2010.11.022

6. Díaz-Maroto MC, Pérez-Coello MS, Cabezudo MD (2002) Effect of different drying methods on the volatile components of parsley (Petroselinum crispum L.). Eur Food Res Technol 215:227-230. https://doi.org/10.1007/s00217-002-0529-7

7. Ali A, Oon CC, Chua BL et al (2020) Volatile and polyphenol composition, anti-oxidant, anti-diabetic and anti-aging properties, and drying kinetics as affected by convective and hybrid vacuum microwave drying of Rosmarinus officinalis L. Ind Crops Prod. https://doi.org/10.1016/j.indcrop.2020.112463

8. Therdthai N, Zhou W (2009) Characterization of microwave vacuum drying and hot air drying of mint leaves (Mentha cordifolia Opiz ex Fresen). J Food Eng 91:482-489. https://doi. org/10.1016/j.jfoodeng.2008.09.031

9. Wojdyło A, Figiel A, Legua P et al (2016) Chemical composition, antioxidant capacity, and sensory quality of dried jujube fruits as affected by cultivar and drying method. Food Chem 207:170-179. https://doi.org/10.1016/j.foodchem.2016.03.099

10. Usai M, Marchetti M, Foddai M et al (2011) Influence of different stabilizing operations and storage time on the composition of essential oil of thyme (Thymus officinalis L.) and rosemary (Rosmarinus officinalis L.). LWT Food Sci Technol 44:244-249. https://doi.org/10.1016/j.lwt.2010.05.024

11. Calín-Sánchez Á, Lech K, Szumny A et al (2012) Volatile composition of sweet basil essential oil (Ocimum basilicum L.) as affected by drying method. Food Res Int 48:217-225. https://doi. org/10.1016/j.foodres.2012.03.015

12. Martín A, Hernández A, Aranda E et al (2017) Impact of volatile composition on the sensorial attributes of dried paprikas. Food Res Int 100:691-697. https://doi.org/10.1016/j.foodr es.2017.07.068

13. Figiel A, Szumny A, Gutiérrez-Ortíz A, Carbonell-Barrachina ÁA (2010) Composition of oregano essential oil (Origanum vulgare) as affected by drying method. J Food Eng 98:240-247. https://doi. org/10.1016/j.jfoodeng.2010.01.002

14. Ghasemi Pirbalouti A, Salehi S, Craker L (2017) Effect of drying methods on qualitative and quantitative properties of essential oil from the aerial parts of coriander. J Appl Res Med Aromat Plants 4:35-40. https://doi.org/10.1016/j.jarmap.2016.07.006

15. de Torres C, Díaz-Maroto MC, Hermosín-Gutiérrez I, PérezCoello MS (2010) Effect of freeze-drying and oven-drying on volatiles and phenolics composition of grape skin. Anal Chim Acta 660:177-182. https://doi.org/10.1016/j.aca.2009.10.005

16. Pimenta Inada KO, Nunes S, Martínez-blázquez JA et al (2020) Effect of high hydrostatic pressure and drying methods on phenolic compounds profile of jabuticaba (Myrciaria jaboticaba) peel and seed. Food Chem 309:125794. https://doi.org/10.1016/j.foodc hem.2019.125794

17. Singleton VL, Orthofer R, Lamuela-Raventos RM (1999) Analysis of total phenols and other oxidation substrates and antioxidants by means of Folin-Ciocalteu reagent. Methods Enzymol 119:152-178

18. Kim DO, Jeong SW, Lee CY (2003) Antioxidant capacity of phenolic phytochemicals from various cultivars of plums. Food Chem 81:321-326. https://doi.org/10.1016/S0308-8146(02)00423-5

19. Blasco B, Rios JJ, Cervilla LM et al (2008) Iodine biofortification and antioxidant capacity of lettuce: potential benefits for cultivation and human health. Ann Appl Biol 152:289-299. https://doi. org/10.1111/j.1744-7348.2008.00217.x

20. Zam W, Bashour G, Abdelwahed W, Khayata W (2012) Separation and purification of proanthocyanidins extracted from pomegranate 's peels (Punica Granatum). Int J Pharm Sci Nanotechnol 5:1808-1813

21. Gawlik-Dziki U (2012) Dietary spices as a natural effectors of lipoxygenase, xanthine oxidase, peroxidase and antioxidant agents.
LWT Food Sci Technol 47:138-146. https://doi.org/10.1016/j. lwt.2011.12.022

22. Ložiene K, Venskutonis PR, Šipailiene A, Labokas J (2007) Radical scavenging and antibacterial properties of the extracts from different Thymus pulegioides L. chemotypes. Food Chem 103:546-559. https://doi.org/10.1016/j.foodchem.2006.08.027

23. Yu L, Perret J, Harris M et al (2003) Antioxidant properties of bran extracts from "akron" wheat grown at different locations. J Agric Food Chem 51:1566-1570. https://doi.org/10.1021/jf020 $950 \mathrm{z}$

24. Re R, Pellegrini N, Proteggente A et al (1999) Antioxidant activity applying an improved ABTS radical cation decolorization assay. Free Radic Biol Med 26:1231-1237

25. Athukorala Y, Kim KN, Jeon YJ (2006) Antiproliferative and antioxidant properties of an enzymatic hydrolysate from brown alga, Ecklonia cava. Food Chem Toxicol 44:1065-1074. https ://doi.org/10.1016/j.fct.2006.01.011

26. Priecina L, Karklina D, Kince T (2018) The impact of steamblanching and dehydration on phenolic, organic acid composition, and total carotenoids in celery roots. Innov Food Sci Emerg Technol 49:192-201. https://doi.org/10.1016/j.ifset .2018.01.008

27. Straumite E, Kruma Z, Galoburda R (2015) Pigments in mint leaves and stems. Agron Res 13:1104-1111

28. Tomsone L, Kruma Z (2019) Spectrophotometric analysis of pigments in horseradish by using various extraction solvents. In: Straumite E, Galoburda R (eds) FOODBALT 2019 13th Baltic Conference on Food Science and Technology "FOOD. NUTRITION. WELL-BEING.” pp 210-215

29. Tomsone L, Kruma Z, Galoburda R, Talou T (2013) Composition of volatile compounds of horseradish roots (Armoracia rusticana L.) depending on the genotype. Proc Latv Univ Agric 29:1-10. https://doi.org/10.2478/plua-2013-0001

30. Tomsone L, Kruma Z (2013) Comparison of different solvents for isolation of phenolic compounds from horseradish (Armoracia rusticana L.) leaves. Res Rural Dev Int Sci Conf Proc 1:104-110

31. Tomsone L (2015) Investigation of biologically active substances in horseradish and lovage. $\mathrm{PhD}$ thesis. LLU, Jelgava

32. Marrelli M, Menichini F, Statti GA et al (2012) Changes in the phenolic and lipophilic composition, in the enzyme inhibition and antiproliferative activity of Ficus carica L. cultivar Dottato fruits during maturation. Food Chem Toxicol 50:726-733. https://doi. org/10.1016/J.FCT.2011.12.025

33. Nunes JC, Lago MG, Castelo-Branco VN et al (2016) Effect of drying method on volatile compounds, phenolic profile and antioxidant capacity of guava powders. Food Chem 197:881-890. https://doi.org/10.1016/J.FOODCHEM.2015.11.050

34. An K, Zhao D, Wang Z et al (2016) Comparison of different drying methods on Chinese ginger (Zingiber officinale Roscoe): changes in volatiles, chemical profile, antioxidant properties, and microstructure. Food Chem 197:1292-1300. https://doi. org/10.1016/j.foodchem.2015.11.033

35. Xiong Y, Zhang P, Luo J et al (2019) Effect of processing on the phenolic contents, antioxidant activity and volatile compounds of sorghum grain tea. J Cereal Sci 85:6-14. https://doi.org/10.1016/J. JCS.2018.10.012

36. Kḷava D, Kampuse S, Tomsone L et al (2018) Effect of drying technologies on bioactive compounds maintenance in pumpkin by-products. Agron Res 16:1728-1741. https://doi.org/10.15159 /AR.18.156

37. Guido LF, Moreira MM (2017) Techniques for extraction of Brewer's spent grain polyphenols: a review. Food Bioprocess Technol 10:1192-1209. https://doi.org/10.1007/s11947-017-1913-4

38. Multari S, Marsol-Vall A, Keskitalo M et al (2018) Effects of different drying temperatures on the content of phenolic compounds and carotenoids in quinoa seeds (Chenopodium quinoa) from 
Finland. J Food Compos Anal 72:75-82. https://doi.org/10.1016/j. jfca.2018.06.008

39. Lin L, Lei F, Sun DW et al (2012) Thermal inactivation kinetics of Rabdosia serra (Maxim.) Hara leaf peroxidase and polyphenol oxidase and comparative evaluation of drying methods on leaf phenolic profile and bioactivities. Food Chem 134:2021-2029. https://doi.org/10.1016/j.foodchem.2012.04.008

40. Lim YY, Murtijaya J (2007) Antioxidant properties of Phyllanthus amarus extracts as affected by different drying methods. LWT Food Sci Technol 40:1664-1669. https://doi.org/10.1016/J. LWT.2006.12.013

41. Kubra IR, Jagan Mohan Rao L (2012) Microwave drying of ginger (Zingiber officinale Roscoe) and its effects on polyphenolic content and antioxidant activity. Int J Food Sci Technol 47:23112317. https://doi.org/10.1111/j.1365-2621.2012.03104.x

42. Vagiri M, Jensen M (2017) Influence of juice processing factors on quality of black chokeberry pomace as a future resource for colour extraction. Food Chem 217:409-417. https://doi.org/10.1016/j. foodchem.2016.08.121

43. Aguilera Y, Dueñas M, Estrella I et al (2010) Evaluation of phenolic profile and antioxidant properties of Pardina lentil as affected by industrial dehydration. J Agric Food Chem 58:10101-10108. https://doi.org/10.1021/jf102222t

44. Kumar N, Pruthi V (2014) Potential applications of ferulic acid from natural sources. Biotechnol Rep 4:86-93. https://doi. org/10.1016/J.BTRE.2014.09.002

45. Braham F, Carvalho DO, Almeida CMR et al (2019) Online HPLC-DPPH screening method for evaluation of radical scavenging phenols extracted from Moringa oleifera leaves. S Afr J Bot. https://doi.org/10.1016/j.sajb.2019.04.001

46. Apak R, Özyürek M, Güçlü K, Çapanołlu E (2016) Antioxidant activity/capacity measurement. 1. Classification, physicochemical principles, mechanisms, and electron transfer (ET)-based assays. J Agric Food Chem 64:997-1027. https://doi.org/10.1021/acs. jafc. 5 b04739

47. Wang Y, Johnson-Cicalese J, Singh AP, Vorsa N (2017) Characterization and quantification of flavonoids and organic acids over fruit development in American cranberry (Vaccinium macrocarpon) cultivars using HPLC and APCI-MS/MS. Plant Sci 262:91-102. https://doi.org/10.1016/j.plantsci.2017.06.004

48. Simpson GLW, Ortwerth BJ (2000) The non-oxidative degradation of ascorbic acid at physiological conditions. Biochim Biophys Acta 1501:12-24. https://doi.org/10.1016/S0925-4439(00)00009 $-0$

49. Wyrzykowski D, Hebanowska E, Nowak-Wiczk G et al (2011) Thermal behaviour of citric acid and isomeric aconitic acids. J Therm Anal Calorim 104:731-735. https://doi.org/10.1007/s1097 3-010-1015-2

50. Meher SP, Ashok Reddy K, Manohar Rao D (2018) Effect of PEG-6000 imposed drought stress on RNA content, relative water content (RWC), and chlorophyll content in peanut leaves and roots. Saudi J Biol Sci 25:285-289. https://doi.org/10.1016/j. sjbs.2017.04.008

51. Zhang Y, Liu G (2018) Effects of cesium accumulation on chlorophyll content and fluorescence of Brassica juncea L. J Environ Radioact 195:26-32. https://doi.org/10.1016/j.jenvr ad.2018.09.017

52. Di Cesare LF, Forni E, Viscardi D, Nani RC (2004) Influence of drying techniques on the volatile phenolic compounds, chlorophyll and colour of oregano (Origanum vulgare L. ssp. prismaticum Gaudin). Ital J Food Sci 16:165-175

53. Chen K, Roca M (2019) Cooking effects on bioaccessibility of chlorophyll pigments of the main edible seaweeds. Food Chem 295:101-109. https://doi.org/10.1016/J.FOODC HEM.2019.05.092

54. Sánchez C, Baranda AB, Martínez de Marañón I (2014) The effect of high pressure and high temperature processing on carotenoids and chlorophylls content in some vegetables. Food Chem 163:3745. https://doi.org/10.1016/J.FOODCHEM.2014.04.041

55. Diop Ndiaye N, Dhuique-Mayer C, Cisse M, Dornier M (2011) Identification and thermal degradation kinetics of chlorophyll pigments and ascorbic acid from Ditax Nectar (Detarium senegalense J.F. Gmel). J Agric Food Chem 59:12018-12027. https ://doi.org/10.1021/jf203582k

56. Arslan D, Özcan MM (2010) Study the effect of sun, oven and microwave drying on quality of onion slices. LWT Food Sci Technol 43:1121-1127. https://doi.org/10.1016/j.lwt.2010.02.019

57. Heaton JW, Marangoni AG (1996) Chlorophyll degradation in processed foods and senescent plant tissues. Trends Food Sci Technol 7:8-15. https://doi.org/10.1016/0924-2244(96)81352-5

58. Frede K, Schreiner M, Baldermann S (2019) Light quality-induced changes of carotenoid composition in pak choi Brassica rapa ssp. chinensis. J Photochem Photobiol B Biol 193:18-30. https://doi. org/10.1016/j.jphotobiol.2019.02.001

59. Kotíková Z, Sulc M, Lachman J et al (2016) Carotenoid profile and retention in yellow-, purple- and red-fleshed potatoes after thermal processing. Food Chem 197:992-1001. https://doi.org/10.1016/J. FOODCHEM.2015.11.072

60. Topuz A, Dincer C, Özdemir KS et al (2011) Influence of different drying methods on carotenoids and capsaicinoids of paprika (Cv.; Jalapeno). Food Chem. https://doi.org/10.1016/j.foodc hem.2011.05.035

61. Zhang Z, Wei Q, Nie M et al (2018) Microstructure and bioaccessibility of different carotenoid species as affected by hot air drying: Study on carrot, sweet potato, yellow bell pepper and broccoli. LWT Food Sci Technol 96:357-363. https://doi. org/10.1016/j.lwt.2018.05.061

62. Petrović S, Drobac M, Ušjak L et al (2017) Volatiles of roots of wild-growing and cultivated Armoracia macrocarpa and their antimicrobial activity, in comparison to horseradish A. rusticana. Ind Crops Prod 109:398-403. https://doi.org/10.1016/j.inder op.2017.08.056

63. Kroener EM, Buettner A (2017) Unravelling important odorants in horseradish (Armoracia rusticana). Food Chem. https://doi. org/10.1016/j.foodchem.2017.04.042

64. Szumny A, Figiel A, Gutiérrez-Ortíz A, Carbonell-Barrachina ÁA (2010) Composition of rosemary essential oil (Rosmarinus officinalis) as affected by drying method. J Food Eng 97:253-260. https://doi.org/10.1016/j.jfoodeng.2009.10.019

Publisher's Note Springer Nature remains neutral with regard to jurisdictional claims in published maps and institutional affiliations. 